Original Article

\title{
Use of MALDI-TOF for identification and surveillance of gram- negative bacteria in captive wild psittacines
}

\author{
Uso do MALDI-TOF para identificação e monitoramento de bactérias Gram-negativas \\ em psitacídeos cativos
}

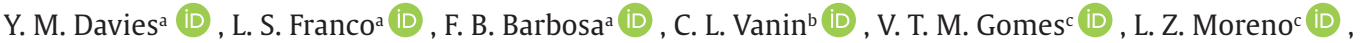 \\ M. R. F. Barbosad (iD), M. I. Z. Satod (iD , A. M. Moreno ${ }^{c}$ (D) and T. Knöbla* (iD \\ aUniversidade de São Paulo - USP, Departamento de Patologia da Faculdade de Medicina Veterinária e Zootecnia, São Paulo, SP, Brasil \\ 'Departamento de Fauna da Secretaria de Infraestrutura e Meio Ambiente do estado de São Paulo, São Paulo, SP, Brasil \\ 'Universidade de São Paulo - USP, Departamento de Medicina Veterinária Preventiva e Saúde Animal da Faculdade de Medicina Veterinária e \\ Zootecnia, São Paulo, SP, Brasil \\ ${ }^{\mathrm{d} C o m p a n h i a ~ A m b i e n t a l ~ d o ~ E s t a d o ~ d e ~ S a ̃ o ~ P a u l o ~-~ C E T E S B, ~ S a ̃ o ~ P a u l o, ~ S P, ~ B r a s i l ~}$
}

\begin{abstract}
Microbiological studies of the sanitary and health status of psittacine birds that will be reintroduced is important in evaluating whether these animals act as carriers of pathogenic agents to other animals and humans. Matrix-assisted laser desorption/ionization time-of-flight mass spectrometry (MALDI-TOF MS) is a faster and more accurate method to identify bacteria than conventional microbiology methods. The aim of this study was to evaluate the health status of psittacines housed in captivity, by assessment of Gram-negative bacteria from fecal microbiota through MALDI- TOF MS identification. The results indicate high frequency of Gram-negative bacteria in feces (96.5\%), especially from the Enterobacteriaceae family (88.7\%). The most prevalent bacteria were Escherichia coli (39.0\%), Proteus vulgaris (12.2\%), Klebsiella spp. (12.1\%) and Raoultella ornithinolytica (8.7\%). Proteus hauseri, Citrobacter spp., Morganella morgannii, Providencia rettgeri, Enterobacter spp. and Escherichia hermannii were isolated with lower frequency. . All these agents are potentially pathogenic for parrots and can cause systemic infections in other animals and humans. These findings reinforce that MALDI- TOF MS proved to be a rapid and accurate method of identification of the microorganism and evaluation of the health status of psittacines, providing relevant data to assist decision-making regarding the sanitary protocols in wildlife centers, and possible future reintroduction of wild birds.
\end{abstract}

Keywords: parrots, psittacine birds, MALDI -TOF MS, enterobacteria, public health.

\begin{abstract}
Resumo
Estudos microbiológicos da sanidade de psitacídeos que serão reintroduzidos são importantes para avaliar se esses animais atuam como portadores de agentes patogênicos para outros animais e humanos. A espectrometria de massa por ionização/dessorção de matriz assistida por laser/tempo de vôo (MALDI-TOF MS) é um método mais rápido e preciso para identificar bactérias na comparação com métodos convencionais de microbiologia. O objetivo deste estudo foi avaliar o estado de saúde de psitacídeos cativos, identificando bactérias Gram-negativas da microbiota fecal por MALDI -TOF MS. Os resultados indicaram alta frequência de bactérias Gram-negativas nas fezes (96,5\%), principalmente da família Enterobacteriaceae (88,7\%). As mais prevalentes foram Escherichia coli (39,0\%), Proteus vulgaris (12,2\%), Klebsiella spp. (12,1\%) e Raoultella ornithinolytica (8,7\%). Proteus hauseri, Citrobacter spp., Morganella morgannii, Providencia rettgeri, Enterobacter spp. e Escherichia hermannii foram isolados com menor frequência. Todos esses agentes são potencialmente patogênicos para os papagaios e podem causar infecções sistêmicas em outros animais e seres humanos. Esses achados reforçam que o MALDI- TOF MS é um método rápido e preciso de identificação do microrganismo e avaliação do estado de saúde dos psitacídeos, fornecendo dados relevantes para auxiliar na tomada de decisões sobre os protocolos sanitários em centros de triagem de animais selvagens e sobre a possibilidade de reintrodução futura.
\end{abstract}

Palavras-chave: aves, psitacídeos, MALDI- TOF MS, enterobactérias, saúde pública.

*e-mail: tknobl@usp.br

Received: January 30, 2020 - Accepted: August 8, 2020

This is an Open Access article distributed under the terms of the Creative Commons Attribution License, which permits unrestricted use, distribution, and reproduction in any medium, provided the original work is properly cited. 


\section{Introduction}

Brazil presents the greatest diversity of parrots in the world, but 25 of the 87 species recognized in Brazilian territories are critically endangered, under threat of extinction or vulnerable (Birdlife International, 2017). The ex situ maintenance and breeding of birds recovered from wildlife trade, followed by rehabilitation and release, represent an alternative for preservation of some species. However, when breeding in captivity, the intestinal and respiratory microbiota of birds may be modified, especially under poor sanitary management (Mattes et al., 2005).

The gastrointestinal microbiome of psittacine freeliving birds has been poorly understood, but the most of reports shows that the normal psittacine bird microbiota is composed by Gram-positive facultative bacteria, that is, aerobic and anaerobic, and producers of lactic acid (Gerlach, 1994; Xenoulis et al., 2010; Allegretti et al., 2014; Saidenberg et al, 2015). However, captive birds usually have a greater diversity of intestinal microbial community, including Gram negative bacteria (Hidasi et al., 2013; Sanches et al., 2017), probably due the influence of anthropogenic action, modified diet and use of antimicrobials (Mattes et al., 2005; Davies et al., 2016a; Clavijo and Flórez, 2018; Pereira et al., 2019).

The high prevalence of Gram-negative opportunistic bacteria, such as Enterobacter spp., Escherichia coli, Klebsiella spp., Citrobacter spp. and Aeromonas spp., increase the health hazard, because these microorganisms can become pathogenic in stressful and adverse situations (Rupley, 1999; Sandmeier and Coutteel, 2006; Davies et al., 2016a). Therefore, a microbiological study of the sanitary and health status of animals that will be reintroduced is important in evaluating whether these animals act as carriers of pathogenic agents to other animals and humans (Braconaro et al., 2015; Davies et al., 2016a; Gioia Di-Chiacchio et al., 2018), and can provide relevant data to assist zoo-sanitary protocols and the management of birds in wildlife centers (Dutra et al., 2016).

Clinical microbiology has developed continuously and there has been a constant search for new techniques for rapid and accurate identification of pathogens (Cherkaoui et al., 2010; Stępień-Pyśniak et al., 2017). In comparison with conventional biochemical or phenotypic tests, MALDI-TOF MS has been increasingly applied in veterinary microbiology diagnostics (Davies et al., 2018; Moreno et al., 2018; Van Driessche et al., 2019; Ulrich et al., 2020).

The MALDI-TOF MS system is used successfully for precise identification of bacteria isolated from various types of specimens (Stępień-Pyśniak et al., 2017; Davies et al., 2016b; Cabral et al., 2020). Therefore, species identification would improve timeliness and reduce isolate identification costs in clinical bacteriology laboratories (Cherkaoui et al., 2010).

The aim of this study was to evaluate the health status of psittacines housed in captivity in the state of São Paulo, Brazil by assessment of Gram-negative bacteria from fecal microbiota through MALDI- TOF MS identification, assist in the development of more effective sanitary maintenance protocols, and possible future reintroduction of wild birds.

\section{Materials and Methods}

The development of this project was approved by the Ethics Committee on Animal Use of the School of Veterinary Medicine and Animal Science of the University of São Paulo (USP-FMVZ), protocol number 5174111215 and has SISBIO license: 46561-2.

\subsection{Animals}

A total of 58 psittacines were evaluated, male and female (not sexed birds), of different ages, which were housed in captivity at the state of São Paulo, Brazil. The birds were fed with seeds and grains and drinking water ad libitum and were kept in individual enclosures. The birds have not received antibiotic treatment in the last six months prior to this study.

Among the animals collected in this period are bluefronted Amazon parrot (Amazona aestiva) $(\mathrm{n}=22)$, Mangrove parrot (Amazona amazonica) $(\mathrm{n}=2)$, Galician parrot (Amazona xanthops) $(\mathrm{n}=1)$, Blue macaw (Anodorhynchus hyacinthinus) $(\mathrm{n}=2)$, Blue-and-yellow macaw (Ara ararauna) $(\mathrm{n}=15)$, Scarlet macaw (Ara macao) $(\mathrm{n}=12)$, and Red-andgreen macaw (Ara chloropterus) $(\mathrm{n}=4)$.

\subsection{Microbiological evaluation}

Stool samples were collected from individual birds. The material was identified, packed and kept refrigerated until referral to the Laboratory of Avian Medicine at the Department of Pathology of FMVZ-USP for microbiological culture and isolation. The individual samples were inoculated in $2 \mathrm{~mL}$ of BHI broth (brain heart infusion, Difco ${ }^{\mathrm{TM}}$ ) and incubated at $37^{\circ} \mathrm{C}$ for $24 \mathrm{~h}$. The isolation was performed on MacConkey agar (DifCo ${ }^{\mathrm{TM}}$ ) and incubated at $37^{\circ} \mathrm{C}$ for $24 \mathrm{~h}$. Then, all different morphotypes were selected (one to three different bacteria species per bird) and maintained at $-80^{\circ} \mathrm{C}$ in $\mathrm{BHI}$ with $30 \%$ of glycerol, for further identification by MALDI-TOF MS.

\subsection{MALDI-TOF MS identification}

For MALDI-TOF MS (Matrix-assisted laser desorption/ ionization time-of-flight mass spectrometry) sample preparation, bacterial proteins were extracted using an ethanol/formic acid protocol (Kuhnert et al., 2012). The isolates were seeded on TSA (Tryptic Soy agar, Difco ${ }^{\mathrm{TM}}$ ) incubated at $37^{\circ} \mathrm{C}$ for $18 \mathrm{~h}$. Then, one colony of each isolate was mixed in $300 \mu \mathrm{L}$ of deionized water. Nine hundred microliters of absolute ethanol were added to each sample. The tubes were mixed by inversion and centrifuged for $3 \mathrm{~min}$ at 12,800 rpm. The supernatant was removed, and the samples are dried at room temperature. After, the pellet was resuspended in $35 \mu \mathrm{L}$ of formic acid (70\%) and then, $35 \mu \mathrm{L}$ of acetonitrile were added. Samples were mixed by inversion and centrifuged at 12,800 $\mathrm{g}$ for $3 \mathrm{~min}$. The supernatant (protein suspension) was removed.

Isolates were tested in duplicate. The protein suspension $(1 \mu \mathrm{L})$ was transferred to a polished steel MALDI target plate (Bruker Daltonik) and allowed to dry at room temperature. The sample was overlaid with $1 \mu \mathrm{L}$ of matrix (10 mg $\alpha$-cyano-4-hydroxy-cinnamic acid $\mathrm{mL}^{-1}$ in $50 \%$ acetonitrile/ $2.5 \%$ trifluoroacetic acid), and mass spectra 
in the 2-20 kDa range were acquired using a Microflex ${ }^{\mathrm{TM}}$ mass spectrometer (Bruker Daltonik). For the MALDI-TOF MS analysis, the spectra were loaded into MALDI BioTyper ${ }^{\mathrm{TM}} 3.0$ and compared with the manufacturer's library, which resulted in the $\log$ (score) value. Standard Bruker interpretative criteria were applied; scores $\geq 2.0$ were accepted for species assignment and scores $\geq 1.7$ but $\leq 2.0$ for genus identification.

\section{Results}

Table 1 shows the distribution of Gram-negative bacteria identified. A total of 115 colonies were selected and identified. Of these isolates, 102/115(88.7\%) were from Enterobacteriaceae family, and 13/115 (11.3\%) were to the families Moraxellaceae (Acinetobacter johnsonii) (0.9\%), Aeromonadaceae (Aeromonas spp.) (1.7\%), Alcaligenaceae (Alcaligenes faecalis) (3.5\%) and Pseudomonadaceae (Pseudomonas spp.) (1.7\%). Among the Enterobacteriaceae, the most frequently isolated species was Escherichia coli (39.0\%). Other genera of bacteria that were isolated less frequently were Proteus vulgaris (12.2\%), Raoultella ornithinolytica (8.7\%), Klebsiella oxytoca (7.8\%), Klebsiella pneumoniae (4.3\%), Citrobacter spp. (4.3\%), Proteus hauseri (4.3\%), Morganella morgannii (3.5\%), Providencia rettgeri (1.7\%), Enterobacter spp. (1.7\%) and Escherichia hermannii $(0.9 \%)$.

All of the birds evaluated presented Gram negative bacteria in their fecal microbiota, except for two birds (2/58), an Amazona aestiva and an Ara ararauna. One to three different bacterial species per bird were isolated: $18.9 \%$ $(11 / 58)$ of birds presented a single Gram-negative pathogen, while $81.1 \%$ (45/58) presented a mix culture, composed by two (31/58) and three (14/58) bacteria species. Escherichia coli stood out with the highest frequency (10/11), among single isolates. The mixed culture were further grouped in 24 distinct profiles, with predominance of Escherichia coli. The higher frequency mixed profiles were composed by Escherichia coli associated with Proteus spp. (7/56) and Escherichia coli associated with Raoultella ornithinolytica (4/56). These data were showed on Table 2.

\section{Discussion}

Routine identification of Gram-negative bacterial isolates from various sources is based on biochemical methods, and is most often confirmed by PCR using primers and conditions for different bacteria species. However, the use of species-specific PCR for identification is laborious and requires a large number of suitable species primers (Cunha et al., 2016; Stępień-Pyśniak et al., 2017).

This study used matrix-assisted laser desorption ionization time-of-flight mass spectrometry (MALDI-TOF MS), based on the protein profile of microorganisms, which is a distinctive and unique molecular fingerprint of a species (Kwak et al., 2015; Santos et al., 2015; Davies et al., 2016b; Stępień-Pyśniak et al., 2017; Davies et al., 2018). Here, MALDI-TOF MS was used as a rapid and accurate method for identification of 115 isolates collected from fecal samples of captive psittacine birds.

In terms of cost, Cherkaoui et al. (2010) reported that using MALDI-TOF MS identification, the laboratory would have saved approximately US\$5 per isolate in marginal costs and reduced average turnaround time by more than an 8-h shift, with no loss in accuracy. Seng et al. (2009) found similar results comparing phenotypic

Table 1. Frequency of Gram-negative bacteria in fecal samples from captive parrots. São Paulo, Brazil.

\begin{tabular}{|c|c|c|c|}
\hline Family & $\begin{array}{l}\text { Bacteria } \\
\text { Species }\end{array}$ & $\begin{array}{c}\text { Feces } \\
(\mathbf{n})\end{array}$ & $\begin{array}{c}\text { Percentage } \\
\text { (\%) }\end{array}$ \\
\hline Moraxellaceae & $\begin{array}{c}\text { Acinetobacter } \\
\text { johnsonii }\end{array}$ & 1 & 0.9 \\
\hline \multirow[t]{3}{*}{ Aeromonadaceae } & $\begin{array}{l}\text { Aeromonas } \\
\text { caviae }\end{array}$ & 4 & 3.5 \\
\hline & $\begin{array}{l}\text { Aeromonas } \\
\text { hydrophila }\end{array}$ & 1 & 0.9 \\
\hline & $\begin{array}{l}\text { Aeromonas } \\
\text { salmonicida }\end{array}$ & 1 & 0.9 \\
\hline Alcaligenaceae & $\begin{array}{l}\text { Alcaligenes } \\
\text { faecalis }\end{array}$ & 4 & 3.5 \\
\hline \multirow[t]{12}{*}{ Enterobacteriaceae } & $\begin{array}{c}\text { Citrobacter } \\
\text { braakii }\end{array}$ & 3 & 2.6 \\
\hline & $\begin{array}{l}\text { Citrobacter } \\
\text { freundii }\end{array}$ & 2 & 1.7 \\
\hline & $\begin{array}{l}\text { Enterobacter } \\
\text { absuriae }\end{array}$ & 1 & 0.9 \\
\hline & $\begin{array}{l}\text { Enterobacter } \\
\text { cloacae }\end{array}$ & 1 & 0.9 \\
\hline & $\begin{array}{l}\text { Escherichia } \\
\text { coli }\end{array}$ & 45 & 39.0 \\
\hline & $\begin{array}{l}\text { Escherichia } \\
\text { hermannii }\end{array}$ & 1 & 0.9 \\
\hline & $\begin{array}{c}\text { Klebsiella } \\
\text { oxytoca }\end{array}$ & 9 & 7.8 \\
\hline & $\begin{array}{l}\text { Klebsiella } \\
\text { pneumoniae }\end{array}$ & 5 & 4.3 \\
\hline & $\begin{array}{c}\text { Morganella } \\
\text { morganni }\end{array}$ & 4 & 3.5 \\
\hline & $\begin{array}{l}\text { Proteus } \\
\text { hauseri }\end{array}$ & 5 & 4.3 \\
\hline & $\begin{array}{l}\text { Proteus } \\
\text { vulgaris }\end{array}$ & 14 & 12.2 \\
\hline & $\begin{array}{l}\text { Providencia } \\
\text { rettgeri }\end{array}$ & 2 & 1.7 \\
\hline \multirow[t]{2}{*}{ Pseudomonadaceae } & $\begin{array}{c}\text { Pseudomonas } \\
\text { putida }\end{array}$ & 1 & 0.9 \\
\hline & $\begin{array}{c}\text { Pseudomonas } \\
\text { oleovorans }\end{array}$ & 1 & 0.9 \\
\hline Enterobacteriaceae & $\begin{array}{c}\text { Raoultella } \\
\text { ornithinolytica }\end{array}$ & 10 & 8.7 \\
\hline Total & & 115 & 100 \\
\hline
\end{tabular}


Table 2. Profiles of Gram-negative bacteria isolated from captive parrots. São Paulo, Brazil.

\begin{tabular}{|c|c|c|}
\hline & Profiles & $\begin{array}{l}\text { Birds } \\
(\mathrm{n}=58)\end{array}$ \\
\hline \multirow{2}{*}{$\begin{array}{l}\text { Single } \\
\text { Culture }\end{array}$} & Escherichia coli & 10 \\
\hline & Klebsiella pneumoniae & 1 \\
\hline \multirow{13}{*}{$\begin{array}{l}\text { Mix culture } \\
\text { ( } 2 \text { species) }\end{array}$} & Escherichia coli + Proteus spp. & 7 \\
\hline & $\begin{array}{c}\text { Escherichia coli }+ \\
\text { Raoultella ornithinolytica }\end{array}$ & 4 \\
\hline & Escherichia coli + Aeromonas spp. & 3 \\
\hline & $\begin{array}{l}\text { Escherichia coli }+ \\
\text { Providencia rettgeri }\end{array}$ & 2 \\
\hline & Escherichia coli + Enterobacter spp. & 2 \\
\hline & Escherichia coli + Klebsiella oxytoca & 2 \\
\hline & $\begin{array}{c}\text { Escherichia coli }+ \\
\text { Morganella morganni }\end{array}$ & 2 \\
\hline & Klebsiella spp. + Proteus vulgaris & 3 \\
\hline & $\begin{array}{c}\text { Escherichia coli + } \\
\text { Alcaligenes faecalis }\end{array}$ & 2 \\
\hline & $\begin{array}{l}\text { Escherichia coli }+ \\
\text { Citrobacter braakii }\end{array}$ & 1 \\
\hline & $\begin{array}{c}\text { Acinetobacter johnsonii + } \\
\text { Proteus hauseri }\end{array}$ & 1 \\
\hline & $\begin{array}{l}\text { Citrobacter braakii + } \\
\text { Klebsiella oxytoca }\end{array}$ & 1 \\
\hline & $\begin{array}{c}\text { Raoultella orniyhinolytica }+ \\
\text { Proteus vulgaris }\end{array}$ & 1 \\
\hline
\end{tabular}

\section{Mix culture}

(3 species)

\section{Escherichia coli + Klebsiella spp. +} Proteus spp.

Escherichia coli + Raoultella ornithinolytica + Aeromonas spp.

Escherichia coli + Raoultella ornithinolytica + Klebsiella oxytoca

Escherichia coli +

Raoultella ornithinolytica + Pseudomonas putida

Escherichia coli + Alcaligenes faecalis + Citrobacter freundii

Escherichia coli + Citrobacter braakii + Aeromonas caviae

Escherichia coli + Escherichia hermannii + Proteus vulgaris

Escherichia coli + Morganella morganii + Citrobacter freundii

Escherichia coli + Proteus vulgaris + Morganella morganii

Klebsiella oxytoca + Pseudomonas oleovorans + Proteus vulgaris

Klebsiella oxytoca + Raoultella ornithinolytica + Alcaligenes faecalis

Total methods (EU 4.66-6.06), MALDI-TOF MS (EU 1.43) and other automated identification system (bioMerieux Vitek system)(EU 5.9-8.23), also the mean time required for MALDI-TOF mass spectrometry identification of 1 isolate was $6 \mathrm{~min}$. Despite the advantages associated with lower cost per analysis and faster diagnosis, the high initial investment to acquire the equipment (more than 200 thousand dollars) can be an impediment for the most of veterinary laboratories. According to the results of this study, $96.5 \%$ of the psittacine birds presented colonization by Gram-negative bacteria (Tables 1 and 2). In asymptomatic birds, Gram-negative bacteria should be considered an indication of need for improvement of health management, thereby minimizing the risk of developing opportunistic infections (Boseret et al., 2013). The main issue is not only related to the pathogenicity of certain strains, but the possibility of transmission to other animals and humans (Saidenberg et al., 2012a, Saidenberg et al. 2012b; Gioia Di-Chiacchio et al., 2018).

In this study, MALDI-TOF MS revealed 13/115 (11.3\%) of the isolates belonged to the families Moraxellaceae (Acinetobacter johnsonii), Aeromonadaceae (Aeromonas spp.), Alcaligenaceae (Alcaligenes faecalis) and Pseudomonadaceae (Pseudomonas spp.). Acinetobacter spp. are widely distributed in the environment (soil) and constitute one of the predominant organisms in water. It has evolved as one of the most important nosocomial pathogens in the past decade (Özvatan et al., 2016). There are reports of infection by Acinetobacter spp. associated with mycobacteriosis in falcons (Muller et al., 2010), asymptomatic saffron finch (Sicalis flaveola) seized from illegal wildlife trade (Davies et al., 2016b), in captive grey parrot (Klotz et al., 2018), and in canaries infected by Macrorhabdus ornithogaster (Robino et al., 2019).

Aeromonas spp. are frequently associated with aquatic environments and may lead gastroenteritis and septicemia in humans, after immunosuppression (Panigrahy et al., 1981). It has been described in wild waterfowl birds that can act as carriers of pathogenic Aeromonas species in their intestines (Laviad-Shitrit et al., 2018), in ostriches (Struthio camelus) (França et al., 2009), and asymptomatic saffron finches (Sicalis flaveola) seized from illegal wildlife trade (Davies et al., 2016b).

Pseudomonas spp. is an opportunistic pathogen present in environmental, but virulent or antibiotic resistant strains may be associated with high morbidity and mortality in humans and animals (Giacopello et al., 2015). This pathogen has also been described in cloacal swabs of asymptomatic wild birds (Brittingham et al., 1988) and passerine birds seized from illegal wildlife trade (Davies et al., 2016b; Cunha et al., 2016).

According to Saidenberg et al. (2015), bacteria from the Enterobacteriaceae family are not part of the intestinal microbiota of free-living psittacine birds. However, studies with isolation of $E$. coli from different sites (cloaca, oropharynx and feces), involving different species of birds, whether free-living or captive, symptomatic or asymptomatic, resulted in the identification of different enterobacteria present in the digestive system (Xenoulis et al., 2010; Davies et al., 2016b; Cunha et al., 2016; Sanches et al., 2017; Vaz et al., 2017), suggesting that, kept in 
captivity with adequate sanitary management (Mattes et al., 2005), they could act as asymptomatic carriers (Loiko et al., 2007; Sanches et al., 2017). This group of bacteria can colonize most tissues of birds, and is often considered a secondary pathogen, that is, it will only cause infections in adverse situations, such as immunosuppression or previous treatment with the use of antibiotics (Gerlach, 1994; Davies et al., 2016a). However, in some cases they can act as primary pathogens, since there are substantial differences in the virulence of enterobacteria and in the host's immune response (Gioia Di-Chiacchio et al., 2018).

The data obtained in this study showed a predominance of some species of enterobacteria: Escherichia coli (39.0\%), Proteus vulgaris (12.2\%), Raoultella ornithinolytica (8.7\%), Klebsiella oxytoca (7.8\%), Klebsiella pneumoniae (4.3\%), Citrobacter spp. (4.3\%) and Proteus hauseri (4.3\%) (Table 1). The identification of other genera such as Morganella morgannii (3.5\%), Providencia rettgeri (1.7\%), Enterobacter spp. (1.7\%) and Escherichia hermannii (0.9\%) were less frequently found.

These data are consistent with the results obtained by Davies et al. (2016b) and Cunha et al. (2016), who identified Klebsiella spp., E. coli, Proteus spp., and Citrobacter spp. in stool samples from several species of clinically healthy passerines. On the other hand, in parrot studies, Davies et al. (2016a) and Vaz et al. (2017) reported the presence of Klebsiella pneumoniae, Klebsiella oxytoca, Enterobacter cloacae, Citrobacter freundii and E. coli associated with clinical manifestations.

Due to the opportunistic nature of the agent, isolation only of feces, cloaca or oropharynx is not enough to associate the presence of bacteria with the occurrence of disease. A more accurate assessment of the risk can be obtained with the aid of molecular techniques to search for genes related to bacterial virulence factors, such as the production of adhesins and toxins (Hidasi et al., 2013; Gioia-Di Chiacchio et al., 2018). Also, the pathogenesis of infections by enterobacteria varies depends on the presence of virulence factors (Broberg et al., 2014), and can be aggravated due to resistance to antibiotics (El Fertas-Aissani et al., 2013).

These findings reinforce the accurate microorganism identification and evaluation of the health status of psittacines kept as companion pets, or those that will be reintroduced in the wild, providing relevant data to assist decision-making regarding the sanitary protocols and destination of birds (Dutra et al., 2016). The automated identification system MALDI- TOF MS proved to be a rapid and accurate method of identification of the bacterial isolates, and will serve as an important microbiological screening tool. Supplemental extraction strategies, as well as expanded databases including other bacterial groups of clinical importance, identifiers of resistance to antimicrobials, and genotype markers, will soon enhance the utility of MALDI-TOF MS (Cherkaoui et al., 2010).

\section{Conclusion}

Although the parrots analyzed were apparently in healthy clinical condition, the frequency of isolation of
Gram-negative bacteria, especially enterobacteria, was high. All these agents are potentially pathogenic for parrots and can cause systemic infections in other animals and humans.

In summary, MALDI-TOF MS-based identification provides less expensive and faster bacterial species identification than conventional phenotypic identification methods. This is especially relevant for routine clinical microbiology, since most results can be reported earlier. Further studies would be necessary to determine the virulence and resistance of these strains and the possible risks regarding public health and biodiversity conservation.

\section{Acknowledgements}

CAPES and CNPq research grants are gratefully. This study was financed in part by The Coordenação de Aperfeiçoamento de Pessoal de Nível Superior Brasil (CAPES - Finance Code 001). T.K. is a CNPq fellow (306577/2017-8).

\section{References}

ALLEGRETTI, L., REVOLLEDO, L., ASTOLFI-FERREIRA, C.S., CHACÓN, J.L., MARTINS, L.M., SEIXAS, G.H.F. and FERREIRA, A.J.P., 2014. Isolation and molecular identification of lactic acid bacteria and Bifidobacterium spp. from faeces of the blue-fronted Amazon parrot in Brazil. Beneficial Microbes, vol. 5, no. 4, pp. 497-503. http://dx.doi.org/10.3920/BM2013.0082. PMid:25062609.

BIRDLIFE INTERNATIONAL, 2017 [viewed 10 December 2019]. State of the world's bids: taking the pulse of the planet [online]. Availabe from: https://www.birdlife.org/sowb2018

BOSERET, G., LOSSON, B., MAINIL, J.G., THIRY, E. and SAEGERMAN, C., 2013. Zoonoses in pet birds: review and perspectives. Veterinary Research, vol. 44, no. 36, pp. 1-17. http://dx.doi. org/10.1186/1297-9716-44-36. PMid:23687940.

BRACONARO, P., SAIDENBERG, A.B.S., BENITES, N.R., ZUNIGA, E., DA SILVA, A.M., SANCHES, T.C., ZWARG, T., BRANDÃO, P.E. and MELVILLE, P.A., 2015. Detection of bacteria and fungi and assessment of the molecular aspects and resistance of Escherichia coli isolated from confiscated passerines intended for reintroduction programs. Microbial Pathogenesis, vol. 88, pp. 65-72. http://dx.doi.org/10.1016/j.micpath.2015.08.006. PMid:26279195.

BRITTINGHAM, M.C., TEMPLE, S.A. and DUNCAN, R.M., 1988. A survey of the prevalence of selected bacteria on wild birds. Journal of Wildlife Diseases, vol. 24, no. 2, pp. 299-307. http://dx.doi. org/10.7589/0090-3558-24.2.299. PMid:3286907.

BROBERG, C.A., PALACIOS, M. and MILLER, V.L., 2014. Klebsiella: a long way to go towards understanding this enigmatic jet-setter. F1000prime Reports, vol. 6, no. August, pp. 64. http://dx.doi. org/10.12703/P6-64. PMid:25165563.

CABRAL, B.G., DAVIES, Y.M., MENÃO, M.C., SAIDENBERG, A., GOMES, V.T.M., MORENO, L.Z., SATO, M.I.Z., MORENO, A.M. and KNÖBL, T., 2020. Companion psittacine birds as reservoir of gentamicin and vancomycin-resistant Enterococcus spp. Pesquisa Veterinária Brasileira, vol. 40, no. 2, pp. 129-133. http://dx.doi.org/10.1590/1678-5150-pvb-6147.

CHERKAOUI, A., HIBBS, J., EMONET, S., TANGOMO, M., GIRARD, M., FRANCOIS, P. and SCHRENZEL, J., 2010. Comparison of two matrix-assisted laser desorption ionization-time of flight mass spectrometry methods with conventional phenotypic identification for routine identification of bacteria to the species 
level. Journal of Clinical Microbiology, vol. 48, no. 4, pp. 11691175. http://dx.doi.org/10.1128/JCM.01881-09. PMid:20164271.

CLAVIJO, V. and FLÓREZ, M.J.V., 2018. The gastrointestinal microbiome and its association with the control of pathogens in broiler chicken production: a review. Poultry Science, vol. 97, no. 3, pp. 1006-1021. http://dx.doi.org/10.3382/ps/pex359. PMid:29253263.

CUNHA, M.P., GUIMARÃES, M., DAVIES, Y., MILANELO, L. and KNÖBL, T., 2016. Bactérias gram-negativas em cardeais (Paroaria coronata e Paroaria dominicana) apreendidos do tráfico de animais silvestres. Brazilian Journal of Veterinary Research and Animal Science, vol. 53, no. 1, pp. 107-111. http://dx.doi.org/10.11606/ issn.1678-4456.v53i1p107-111.

DAVIES, Y.M., CUNHA, M.P., OLIVEIRA, M.G., OLIVEIRA, M.C., PHILADELPHO, N., ROMERO, D.C., MILANELO, L., GUIMARÃES, M.B., FERREIRA, A.J.P., MORENO, A.M., SÁ, L.R. and KNÖBL, T., 2016a. Virulence and antimicrobial resistance of Klebsiella pneumoniae isolated from passerine and psittacine birds. Avian Pathology, vol. 45, no. 2, pp. 194-201.

DAVIES, Y.M., GUIMARÃES, M.B., MILANELO, L., OLIVEIRA, M.G.X., GOMES, V.T.D.M., AZEVEDO, N.P., CUNHA, M.P.V., MORENO, L.Z., ROMERO, D.C., CHRIST, A.P.G., SATO, M.I.Z., MORENO, A.M., FERREIRA, A.J.P., SÁ, L.R.M. and KNÖBL, T., 2016b. A survey on gram-negative bacteria in saffron finches (Sicalis flaveola) from illegal wildlife trade in Brazil. Brazilian Journal of Veterinary Research and Animal Science, vol. 53, no. 3, pp. 286. http:// dx.doi.org/10.11606/issn.1678-4456.bjvras.2016.109042.

DAVIES, Y.M., XAVIER DE OLIVEIRA, M.G., PAULO VIEIRA CUNHA, M., SOARES FRANCO, L., PULECIO SANTOS, S.L., ZANOLLI MORENO, L., TÚLIO DE MOURA GOMES, V., ZANOLLI SATO, M.I., SCHIAVO NARDI, M., MICKE MORENO, A., BECKER SAIDENBERG, A., ROSE MARQUES DE SÁ, L. and KNÖBL, T., 2018. Edwardsiella tarda outbreak affecting fishes and aquatic birds in Brazil. The Veterinary Quarterly, vol. 38, no. 1, pp. 99-105. http:// dx.doi.org/10.1080/01652176.2018.1540070. PMid:30668277.

DUTRA, L.M., YOUNG, R.J., GALDINO, C.A. and VASCONCELLOS, A.S., 2016. Apprenhended saffron finches now how to survive predators? A careful look at reintroduction candidates. Behavioural Processes, vol. 125, pp. 6-12. http://dx.doi. org/10.1016/j.beproc.2016.01.007. PMid:26827615.

EL FERTAS-AISSANI, R., MESSAI, Y., ALOUACHE, S. and BAKOUR, R., 2013. Virulence profiles and antibiotic susceptibility patterns of Klebsiella pneumoniae strains isolated from different clinical specimens. Pathologie Biologie, vol. 61, no. 5, pp. 209-216. http://dx.doi.org/10.1016/j.patbio.2012.10.004. PMid:23218835.

FRANÇA, M., WALKER, R.L., KOKKA, R. and SHIVAPRASAD, H.L., 2009. Aeromonas Species Associated with Necrotizing Enteritis and Septicemia in an Adult Male Ostrich (Struthio camelus). Avian Diseases, vol. 53, no. 2, pp. 310-316. http://dx.doi. org/10.1637/8458-082508-Case.1. PMid:19630242.

GERLACH, H., 1994. Bacteria. In: B.W. RITCHIE, G.J. HARRISON and L.R. HARRISON, eds. Avian Medicine: principles and application. Lake Worth, Fla: Wingers Pub, pp. 1384.

GIACOPELLO, C., FOTI, M., FISICHELLA, V. and LO PICCOLO, F., 2015. Antibiotic-Resistance patterns of Gram-negative bacterial isolates from breeder canaries (Serinus canaria domestica) with clinical disease. Journal of Exotic Pet Medicine, vol. 24, no. 1, pp. 84-91. http://dx.doi.org/10.1053/j.jepm.2014.12.009.

GIOIA DI-CHIACCHIO, R.M., CUNHA, M.P.V., DE SÁ, L.R.M., DAVIES, Y.M., PEREIRA, C.B.P., MARTINS, F.H., MUNHOZ, D.D., ABE, C.M., FRANZOLIN, M.R., DOS SANTOS, L.F., GUTH, B.E.C., ELIAS, W.P., PIAZZA, R.M.F. and KNÖBL, T., 2018. Novel Hybrid of typical enteropathogenic Escherichia coli and Shiga-Toxin-Producing E. coli (tEPEC/STEC) emerging from pet birds. Frontiers in
Microbiology, vol. 9, pp. 1-9. http://dx.doi.org/10.3389/ fmicb.2018.02975. PMid:30574131.

HIDASI, H.W., HIDASI-NETO, J., MORAES, D.M.C., LINHARES, G.F.C., JAYME, V.S. and ANDRADE, M.A., 2013. Enterobacterial detection and Escherichia coli antimicrobial resistance in parrots seized from the illegal wildlife trade. Journal of Zoo and Wildlife Medicine, vol. 44, no. 1, pp. 1-7. http://dx.doi.org/10.1638/10427260-44.1.1. PMid:23505696.

KLOTZ, P., JACOBMEYER, L., STAMM, I., LEIDNER, U., PFEIFER, Y., SEMMLER, T., PRENGER-BERNINGHOFF, E. and EWERS, C., 2018. Carbapenem-resistant Acinetobacter baumannii ST294 harbouring the OXA-72 carbapenemase from a captive grey parrot. The Journal of Antimicrobial Chemotherapy, vol. 73, no. 4, pp. 1098-1100. http://dx.doi.org/10.1093/jac/dkx490. PMid:29309610.

KUHNERT, P., BISGAARD, M., KORCZAK, B.M., SCHWENDENER, S., CHRISTENSEN, H. and FREY, J., 2012. Identification of animal Pasteurellacea by MALDI-TOF mass spectrometry. Journal of Microbiological Methods, vol. 89, no. 1, pp. 1-7. http://dx.doi. org/10.1016/j.mimet.2012.02.001. PMid:22343217.

KWAK, H.L., HAN, S.K., PARK, S., PARK, S.H., SHIM, J.Y., OH, M., RICKE, S.C. and KIM, H., 2015. Development of a rapid and accurate identification method for Citrobacter species isolated from pork products using a matrix-assisted laser-desorption ionization time-offlight mass spectrometry (MALDI-TOF MS). Journal of Microbiology and Biotechnology, vol. 25, no. 9, pp. 1537-1541. http://dx.doi.org/10.4014/jmb.1503.03071. PMid:26017224.

LAVIAD-SHITRIT, S., IZHAKI, I., ARAKAWA, E. and HALPERN, M., 2018. Wild waterfowl as potential vectors of Vibrio cholerae and Aeromonas species. Tropical Medicine \& International Health, vol. 23, no. 7, pp. 758-764. http://dx.doi.org/10.1111/ tmi.13069. PMid:29733476.

LOIKO, M.R., ABILHEIRA, F.S., GUEDES, N.R., PASSOS, D.T., WEIMER, T.A., OLIVEIRA, S.J. and ALLYGAYER, M.C., 2007. Identificação da microbiota da orofaringe e cloaca em filhotes de araraazul-grande (Anodorhynchus hyacinthinus) de vida livre do Pantanal-MS. Revista de Iniciação Científica da ULBRA, vol. 6, no. 6, pp. 29-35.

MATTES, B.R., CONSIGLIO, S.A.S., ALMEIDA, B.Z., GUIDO, M.C., ORSI, R.B., SILVA, R.M., COSTA, A., FERREIRA, A.J.P. and KNÖBL, T., 2005. Influência da biossegurança na colonização intestinal por Escherichia coli em psitacídeos. Arquivos do Instituto Biológico, vol. 72, pp. 13-16.

MORENO, L.Z., MATAJIRA, C.E., POOR, A.P., MESQUITA, R.E., GOMES, V.T., SILVA, A.P.S., AMIGO, C.R., CHRIST, A.P., BARBOSA, M.R.F., SATO, M.I.Z. and MORENO, A.M., 2018. Identification through MALDI-TOF mass spectrometry and antimicrobial susceptibility profiling of bacterial pathogens isolated from sow urinary tract infection. The Veterinary Quarterly, vol. 38, no. 1, pp. 1-8. http:// dx.doi.org/10.1080/01652176.2017.1397302. PMid:29090643.

MULLER, M.G., GEORGE, A.R. and WALOCHNIK, J., 2010. Acinetobacter baumammii in Localised Cutaneous Mycobacteriosis in Falcons. Veterinary Medicine International, vol. 2010, pp. 1-7. http://dx.doi.org/10.4061/2010/321797. PMid:20871867.

ÖZVATAN, T., AKALIN, H., SINIRTAŞ, M., OCAKOĞLU, G., YILMAZ, E., HEPER, Y., KELEBEK, N., IŞÇIMEN, R. and KAHVECI, F., 2016. Nosocomial Acinetobacter pneumonia: treatment and prognostic factors in 356 cases. Respirology (Carlton, Vic.), vol. 21, no. 2, pp. 363-369. http://dx.doi.org/10.1111/ resp12698. PMid:26635315.

PANIGRAHY, B., MATHEWSON, J.J., HALL, C.F. and GRUMBLES, L.C., 1981. Unsual disease conditions in pet and aviary birds. 
Journal of the American Veterinary Medical Association, vol. 178, no. 4, pp. 394-395. PMid:7240000.

PEREIRA, R., BORTOLUZZI, C., DURRER, A., FAGUNDES, N.S., PEDROSO, A.A., RAFAEL, J.M., PERIM, J.E.L., ZAVARIZE, K.C., NAPTY, G.S., ANDREOTE, F.D., COSTA, D.P. and MENTEN, J.F.M., 2019. Performance and intestinal microbiota of chickens receiving probiotic in the feed and submitted to antibiotic therapy. Journal of Animal Physiology and Animal Nutrition, vol. 103, no. 1, pp. 72-86. http://dx.doi.org/10.1111/jpn.13004. PMid:30485573.

ROBINO, P., FERROCINO, I., ROSSI, G., DOGLIERO, A., ALESSANDRIA, V., GROSSO, L., GALOSI, L., TRAMUTA, C., COCOLIN, L. and NEBBIA, P., 2019. Changes in gut bacterial communities in canaries infected by Macrorhabdus ornithogaster. Avian Pathology, vol. 48, no. 2, pp. 111-120. http://dx.doi.org/10.1080/03079457.20 18.1553294. PMid:30499334.

RUPLEY, A.E., 1999. Manual de clínica aviária. São Paulo: Ed. Roca. $582 \mathrm{p}$.

SAIDENBERG, A.B., GUEDES, N.M.R., SEIXAS, G.H.F., ALLAGAYER, M.C., ASSIS, E.P., SILVEIRA, L.F., MELVILLE, P.A. and BENITES, N.R., 2012a. A survey for Escherichia coli in asymptomatic free-ranging parrots. International Scholarly Research Network Veterinary Science, vol. 2012, pp. 984813. PMid:23738135.

SAIDENBERG, A.B., TEIXEIRA, R.H.F., GUEDES, N.M.R., ALLGAYER, M.C. MELVILLE, P.A. and BENITES, N.R., 2012b. Molecular detection of enteropathogenic Escherichia coli in asymptomatic captive psittacines. Pesquisa Veterinária Brasileira, vol. 32, no. 9, pp. 922-926. http://dx.doi.org/10.1590/S0100-736X2012000900017.

SAIDENBERG, A.B.S., GILARDI, J.D., MUNN, C.A. and KNÖBL, T., 2015. Evaluation of fecal gram stains and prevalence of endoparasites in free-living Macaws. Atas de Saúde Ambiental, vol. 3, pp. 3-11.

SANCHES, L.A., GOMES, M., TEIXEIRA, R.H.F., CUNHA, M.P.V., OLIVEIRA, M.G.X., VIEIRA, M.A.M., GOMES, T.A.T. and KNOBL, T., 2017. Captive wild birds as reservoirs of enteropathogenic $E$. coli (EPEC) and Shiga-toxin producing E. coli (STEC). Brazilian Journal of Microbiology, vol. 48, no. 4, pp. 760-763. http://dx.doi. org/10.1016/j.bjm.2017.03.003. PMid:28619663.

SANDMEIER, P. and COUTTEEL, P., 2006. Management of canaries, finches and mynahs. In: G.J. HARRISON and LIGHTFOOT, T. L., eds. Clinical avian medicine. Florida: Editor Spix Publishing, vol. 2, p.896-897.
SANTOS, T., CAPELO, J.L., SANTOS, H.M., OLIVEIRA, I., MARINHO, C., GONÇALVES, A., ARAÚJO, J. E., POETA, P., and IGREJAS, G., 2015. Use of MALDI-TOF mass spectrometry fingerprinting to characterize Enterococcus spp. and Escherichia coli isolates. Journal of Proteomics, vol. 127, Part B, pp. 321-331.

SENG, P., DRANCOURT, M., GOURIET, F., LA SCOLA, B., FOURNIER, P.E., ROLAIN, J.M. and RAOULT, D., 2009. Ongoing revolution in bacteriology: routine identification of bacteria by matrixassisted laser desorption ionization time-of-flight mass spectrometry. Clinical Infectious Diseases, vol. 49, no. 4, pp. 543-551. http://dx.doi.org/10.1086/600885. PMid:19583519.

STĘPIEŃ-PYŚNIAK, D., HAUSCHILD, T., RÓŻAŃSKI, P. and MAREK, A., 2017. MALDI-TOF Mass Spectrometry as a useful tool for identification of Enterococcus spp. from wild birds and differentiation of closely related species. Journal of Microbiology and Biotechnology, vol. 27, no. 6, pp. 1128-1137. http://dx.doi. org/10.4014/jmb.1612.12036. PMid:28285496.

ULRICH, S., GOTTSCHALK, C., STRAUBINGER, R.K., SCHWAIGER, K. and DÖRFELT, R., 2020. Acceleration of the identification of sepsis-inducing bacteria in cultures of dog and cat blood. The Journal of Small Animal Practice, vol. 61, no. 1, pp. 42-45. http://dx.doi.org/10.1111/jsap.13056. PMid:31313312.

VAN DRIESSCHE, L., BOKMA, J., DEPREZ, P., HAESEBROUCK, F., BOYEN, F. and PARDON, B., 2019. Rapid identification of respiratory bacterial pathogens from bronchoalveolar lavage fluid in cattle by MALDI-TOF MS. Scientific Reports, vol. 9, no. 1, pp. 18381. http://dx.doi.org/10.1038/s41598-019-54599-9. PMid:31804604.

VAZ, F.F., SERAFINI, P.P., LOCATELLI-DITTRICH, R., MEURER, R., DURIGON, E.L., DE ARAÚJO, J., THOMAZELLI, L.M., OMETTO, T., SIPINSKI, E.A.B., SEZERBAN, R.M., ABBUD, M.C. and RASO, T.F., 2017. Survey of pathogens in threatened wild red-tailed Amazon parrot (Amazona brasiliensis) nestlings in Rasa Island, Brazil. Brazilian Journal of Microbiology, vol. 48, no. 4, pp. 747-753. http://dx.doi.org/10.1016/j.bjm.2017.03.004. PMid:28629971.

XENOULIS, P.G., GRAY, P.L., BRIGHTSMITH, D., PALCULICT, B., HOPPES, S., STEINER, J.M., TIZARD, I. and SUCHODOLSKI, J.S., 2010. Molecular characterization of the cloacal microbiota of wild and captive parrots. Veterinary Microbiology, vol. 146, no. 3-4, pp. 320-325. http://dx.doi.org/10.1016/j. vetmic.2010.05.024. PMid:20646876. 